\title{
An Introduction to the MSI- model
}

\author{
Yesim Ozek (Corresponding author) \\ Northern Arizona University, Arizona, AZ 86001, USA \\ Tel: 19-28-380-0942Ｅ-mail: yesim.ozek@nau.edu
}

Yasemin Yildiz

University of Essex, Department of Language and Linguistics, Colchester CO4 3SQ, UK

Tel: 44-1206-873-333Ｅ-mail: yaseminuk@hotmail.com

Received: January 10, 2012

doi:10.5539/ells.v2n1p2
Accepted: February 7, 2012

Published: March 1, 2012

URL: http://dx.doi.org/10.5539/ells.v2n1p2

\begin{abstract}
This paper presents the second phase of a preliminary study which had shed light on the significant role of markedness constraints in vocabulary learning (VL). The present study provides an introduction to the Markedness, Strategy and Input (hereafter MSI) Model, which examines the collective relationship between markedness, determination strategies and the role of input in VL.

The interdisciplinary framework of this paper will not only enhance our understanding of second language (L2) vocabulary learning, but also build a bridge between linguistic theory and foreign language teaching. Suggestions for further research within this field and the wider implications of the MSI-model will also be addressed.
\end{abstract}

Keywords: Markedness theory, Vocabulary learning strategies, Implicit vs. Explicit learning

\section{Introduction}

Since the 1960s, a greater emphasis has been placed on language learners, particularly on how learners process new information in a foreign (FL) or second language (L2). According to Spolsky (1989) there are a number of conditions for learning a FL or L2. In his general theory model he suggests that markedness condition is necessary as a linguistic ground for language learning.

Markedness was initially applied to the field of phonetics, with the introduction of Trubetzkoy's (1939) book entitled The Principles of Phonology. The term markedness, however, has not only been applied to phonetics and phonology, but recently also applied to other linguistic fields such as semantics, pragmatics and syntax. Despite the wide application of markedness it remains to be used profoundly within linguistic theory and its direct contribution to pedagogy has been neglected. Based on this limitation, this paper seeks to provide a collective analysis of how markedness interacts with other widely discussed variables in L2 VL, all which is discussed under the MSI-model, which will also be introduced in this study. With the fulfillment of these research objectives, this paper not only aims to build a bridge between linguistic theory and practice, but also to increase the awareness of the role of markedness especially in foreign language education.

\subsection{The Application of Markedness Theory in Language Education}

Trubetzkoy and Jakobson were the first linguists to introduce the idea of 'markedness' in the 1930s and is treated as a language-particular phenomenon. Trubetzkoy approached the term markedness within a descriptive framework and it was initially confined to phonetics (in a pair of opposite phonemes; one characterized as marked, while the other lacks such markedness) and this was reflected in the influential work entitled The Principles of Phonology (1939). Jakobson (1968), however, approached the term markedness within the perspective of language acquisition. The underlying principle of Jakobson's theory is that there is a universal order of acquisition, largely based on phonological oppositions and phonetic properties of segments. Based on the structural contrasts in his theory, Jakobson suggested that the unmarked forms would be the earliest acquired and would also occur in all the world's languages. In sum, a range of diagnostics are used to determine the unmarked sound, such that any sound which is more widely distributed, more phonetically variable, easier to articulate, easier to identify, more frequent across a language and within a language, and acquired earlier are considered to be unmarked. A discussion of the validity of these diagnostics is beyond the scope of this paper, but may be used as a way to provide insight into the asymmetry 
between marked and unmarked items.

A common result of the acquisition of unmarked items before marked items in first language acquisition is a situation described as Emergence of the Unmarked (McCarthy \& Prince, 1994). For instance, reducing a cluster into a singleton, such as Gitanjali's [so] for snow (Gnanadesikan, 2004) is a common example of the Emergence of the Unmarked. By and large markedness has been embraced not only by first and second language phonology, but also by European Structuralism, generative phonology, Chomskyan principles-and-parameters syntax, and other area of linguistics such as semantics and morphology. Unlike Trubetzkoy's and Jakobson's earlier writings, Chomsky \& Halle's (1968) proposed that markedness values are not just present in language-particular mental grammar, but also part of our innate knowledge ('Universal Grammar' (UG)). To put in other words, unmarked structures are those that are governed by UG and which, therefore require only minimal evidence for acquisition. Different degrees of markedness have also been distinguished according to the differing parameter settings of UG. For example, the fact that children start with a pro-drop setting means that non-pro-drop is more marked. The application of markedness by Chomskyan linguistics therefore not only added a new dimension to the term itself, but also further strengthened the applicability of markedness.

Following the above research trends which have applied the term markedness in other linguistic domains, there still stands two limitations regarding its usage. Firstly, its application to other linguistic domains, particularly lexicology (or lexicological development) remains untouched. Secondly, it is left to the hands of theoretical linguists and therefore created a wider gap between theory and practice. This gap may be attributed to the fact that the term markedness at present is a too abstract notion and this situation is also depicted by Rice (2003: 390) "capturing exactly what markedness means is by no means a straightforward task". In addition, such statement of this kind would suggest linguists deliberately develop a specialist terminology to keep ordinary people in the dark, yet it is not just linguists who develop specialist modes of expression as other disciplinary enquiries also do it. Nonetheless, the work of scholars such as Battistella (1990), who considers markedness as a unifying concept in linguistic analysis, is particularly encouraging for the scope of this paper.

In order to analyse markedness within several linguistic domains, including lexical development, this paper will implement Haspelmath's (2006) unified model of markedness which distinguishes twelve different senses of markedness, which are grouped under four broad classes of markedness: markedness as 'complexity', 'difficulty', 'abnormality', 'multicultural dimension'. In this study, the model will be slightly modified, so that it applies only to the target lexical items which are marked in certain respects. See Yildiz \& Ozek (2009), for a more detailed application of the model.

\subsection{Vocabulary Learning Strategies}

The topic of second language vocabulary learning and teaching is a widely examined area in acquisition research as it can enhance our understanding in many aspects, such as linguistic competence, learning processes, mother tongue influence, and pedagogy. Second language research has revealed that "the single most important task facing language learners is acquiring a sufficientlarge vocabulary" (Lewis, 2000:8). In particular, since the 1960s a greater emphasis has been put on the language learners, in particular how successful learners process new information in an L2 and how they can remember the information. Specifically,Joan Rubin's (1975) scholarly work entitled 'What the "Good Language Learner" Can Teach Us' carried the attentionon language learner strategies and suggested that one way to improve this process is to teach learners how to learn more efficiently and effectively. For this purpose, teachers are recommended to increase their student's awareness in using different learning strategies. Subsequently, a wide range of definitions have been provided for language-learning strategies as depicted below:

Specific actions, behaviours, steps, or techniques that students employ- often consciously- to improve their progress in internalizing, storing, retrieving, and using the SL. (Oxford, 1993:175)

The emphasis on strategy identification of successful language learners have also given way to the importance of Strategy Based Instruction (hereafter SBI), either as a separate course or integrated in language instruction. The following statement by Rubin (1990: 282) reflects the importance of SBI:

Often poor learners don't have a clue as to how good learners arrive at their answers and feel they can never perform as good learners do. By revealing the process, this myth can be exposed.

The current literature on Language Learning Strategies (hereafter LLS) imposes two limitations, these are: (1) there are literally hundreds of different, yet often interrelated, LLS (2) there stands to be no unified account of all the strategies and rather classified into differing disciplines: listening, writing, L2 grammar, reading and vocabulary. For the purpose of the research agenda, the present study will be examining the latter strategy, yet we also suggest that these strategies are somewhat overlapping each other; such claim however is beyond the scope of this paper. 
Oxford outlines three main types of direct LLS: memory strategies "aid in entering information into long-term memory and retrieving information when needed for communication", cognitive strategies "used for forming and revising internal mental models and receiving and producing messages in the target language", and compensation strategies "they are needed to overcome any gaps in knowledge of the language" (Oxford, 1990: 71). Oxford also describes three types of indirect LLS: metacognitive strategies "help learners exercise 'executive control' through planning, arranging, focusing, and evaluating their own learning", affective strategies "enable learners to control feelings, motivations, and attitudes related to language learning", and finally, social strategies "facilitate interaction with others, often in a discourse situation" (1990: 71).

A more detailed account of the LLS discussed above is suggested by Schmitt (1997: 207-208). In his taxonomy, he categorized VL strategies into two main groups with 58 individual strategies in total: the ones to determine the meaning of new words when encountered for the first time, and the ones to consolidate meaning when encountered again. The former contains determination and social strategies and the latter contains cognitive, metacognitive, memory and social strategies. Schmitt includes social strategies in both categories since they can be used for both purposes. In general, although the taxonomies cited above may slightly differ in terms of strategies they categorize, they all provide a list of a number of applicable VL strategies and they have inspired many researchers to look into the effects of learning strategies on learning (Sanaoui, 1995; Chamot et al., 1999; Segler et al., 2002; Ghazal, 2007). One of the main objectives of the present study is to investigate the effective use of VL strategies. In so doing, the researchers adopt Schmitt's taxonomy of VL strategies into account and focuses only on the determination strategies as enlisted in Table 1. The reason for the researchers' specific choice of strategies is mainly due to the comprehensibility those strategies during.

[Insert Table 1 here]

There are numerous studies examining LLS and suggest that there are several independent variables which might be interacting with strategy choice and use. For example, cultural and L1 backgrounds (e.g. Parry, 1991, 1993) and personality type (Abraham and Vann, 1987) are linked with successful reading. Similarly, gender (e.g. Gu, 2005; Catalan, 2003), proficiency (e.g. Schmitt, 1997; Harley and Hart, 2000) and learning environment (e.g. Kojic-Sabo and Lightbown, 1999; Leeke and Shaw, 2000) are some of the many factors which influence VL strategies. Previous studies have not however interpreted the direct role of markedness in VL strategy choice and use, and markedness is therefore one of the variables in the present study.

\subsection{The Role of Input in Vocabulary Learning}

In deciding how to develop language learning skills, one should also not deny the role of input in the learning process. Krashen's theory of 'Input Hypothesis' (1985) led a number of studies claiming that there is a strong relationship between 'comprehensible input' and language acquisition (Larsen-Freeman \& Long, 1991; Ellis, 1994; Trimino \& Ferguson, 1994; VanPatten, 1996; Gass \& Mackey, 2006). Krashen's theory explains that learners acquire the language by understanding the messages; more comprehensible input, oral and written, results in more language acquisition (Krashen, 1989).

The role of input in VL has been investigated in various studies (Nation, 2006; Ellis 1994). Input has been considered as consisting two types, such as explicit and implicit. This dichotomy stems from the notion of implicit versus explicit learning (N. Ellis, 1995). Implicit learning refers to unconscious operation whereas the latter is more conscious. Explicit learning involves a search for rules or the application of the given rules. This involves form-focused instruction (N. Ellis, 1994). In vocabulary learning, explicit input aims direct learning; the learner is provided a definition of the lexical item or L1 equivalent. In implicit learning, however, the learner can learn the meaning of a word from an implicit input where he/she is provided with a sample sentence. Here the learner can interpret the meaning of the word from the given context. Thus this refers to meaning-focused instruction.Broadly speaking, input has a mediator role between the learner and the knowledge- i.e. form and meaning- about the item. Having said all these, input is an essential element of instruction in VL.

There have been limited studies focusing on the role of input VLprocess, therefore the current study aims to shed light on how explicit and implicit input helps Turkish learners in L2 vocabulary.

\subsection{Theoretical Framework and Research Questions}

This paper aims to interpret $\mathrm{L} 2 \mathrm{VL}$ within a triangular and interdisciplinary approach, which we propose to discuss under the Markedness, Strategy and Input (MSI) model. The MSI-model will examine the interaction of these three factors in L2 VL, in where markedness embodies the linguistic factors, strategy choice embodies the individual learning styles, and input embodies the role of instruction. The possible interaction between these three factors is depicted in Figure 1 and which also surmises the main enquiry of the current study. 


\section{[Insert Figure 1 here]}

The present study is designed following an experimental approach. Therefore it aims to fulfill the following two research agendas during the experiments:

- $\quad$ to diagnose the role of markedness, input, and strategy use in L2 VL.

- to identify a possible relationship between these three variables and the influence of this relationship on

VL.

Based on the outlined rationale of the MSI-model, this study seeks to address the following research questions:

1) What is the role of markedness in L2 VL?

2) What determination strategies do Turkish adult learners use in L2 VL?

3) What type of input is more effective in L2 VL?

4) Is there any relationship among the markedness constraints, strategy choice and input type in L2 VL?

\section{Methodology}

\subsection{Participants}

This study was conducted with ten native Turkish-speaking first year undergraduate university students studying at the ELT department of a Foundation university in Turkey, in where the medium of education is in English. In Turkey, English functions as a Foreign Language (FL) as opposed to a Second Language (SL). This paper acknowledges the SL and FL difference, however, throughout this paper it uses L2 as a cover term since a direct SL and FL contextual comparison has not been made. The subjects were all at advanced level of English and have not been learning any other foreign language. They were selected randomly by the instructors in the department.

\subsection{Instruments}

The instruments employed to capture the subjects' VL constraints were Think-aloud Protocols and Schmitt's Taxonomy of VL strategies (ibid). To conduct the think-aloud protocols the researchers randomly selected a reading text from an online source which was appropriate for the subjects' proficiency level. The text was entitled as money, and was in English (see Appendix 1). It consisted of 300 words in total, 26 of which were the target lexical items which fall under certain markedness senses (see Table 2). The lexical items are then broadly categorized according to their type of, as outlined in (1a-e):

(1) Type of markedness

a. Morphology: includes words which do not stand alone as a stem.

b. Syllable count: includes polysyllabic words.

c. Semantics: includes words which are polysemic or not transparent.

d. Margin length: includes words which have a complex syllable structure and exhibit consonant clusters

e. Frequency: includes infrequent words (based on Leech, et al., 2001)

\subsection{Procedure}

\subsubsection{Think Aloud \& Recognition Procedure}

The subjects were invited to meet the researchers individually outside their class time. Prior the think-aloud procedure they were given an orientation about the procedure. During the think-aloud procedure, each student was asked to read the selected text in a linear order and provide the correct recognition of the 26 lexical itemswritten in the text (See Appendix 1). While doing this they were given one minute to think aloud and interpret each target lexical item in their mother tongue in order to overcome the limitations of their English verbal ability. They were also asked to speak about the strategies they applied to guess the meaning of the items, and those strategies were labeled in accordance with the strategies enlisted in Table 1. The think-aloud protocols were recorded on paper on the spot by both researchers for the purpose of scorer-reliability.

The main purpose of the above procedure is to identify the learners' success in lexical recognition and their strategy choices.

\subsubsection{Input Procedure}

Following think-aloud procedure the subjects were given a 10 minutes break. They were then provided with the meaning of the lexical items by using implicit and explicit inputs. As part of the controlled procedure, first half of the lexical items were explained in a new sentence within context, while the other half with L1 glosses (see Table 2 
for the classification of the lexical items). The first input is implicit input, while the latter is explicit, and both inputs are in written form. The implicit input is provided prior the explicit input, as they are already in a thinking mode due to the previous think-aloud procedure, which also comes in implicit form. Such approach will allow the students to carryout the tasks with more ease and increase their own oral output before having access to input in their mother-tongue.

A week later, following the think-aloud protocols, the subjects were invited to meet the instructors at a set time. The purpose of the second meeting was to check the effectiveness of the input procedure and this was carried out by giving a list of the target lexical items, in which the subjects were asked to recall the meaning of the items in their mother tongue. This procedure lasts ten minutes for each subject. During this time both instructors monitored the subjects and took notes of the given responses.

\section{Analysis and Results}

\subsection{Research Question 1. What is the Role of Markedness in L2 VL?}

Descriptive statistics was used to analyse the students' interpretations for the target lexical items representing different categories of markedness during the think-aloud procedure. Table 2 summarizes the frequency and ratio scores of these interpretations. The analysis of the data has revealed that the subjects' overall performance in total numbers and percentages according to each markedness constraint were varied. As depicted in Table 2, it seemed that the subjects had difficulties with the target items mainly because of the margin length $67 \%$ incorrect responses, $33 \%$ correct responses). The results further revealed that the respondents had difficulties due to other factors. Those factors were respectively, syllable count (60\% incorrect responses, $40 \%$ correct responses), semantics $(55 \%$ incorrect responses, $45 \%$ correct responses), morphology (55\% incorrect responses, $45 \%$ correct responses) and frequency ( $50 \%$ incorrect responses, $50 \%$ correct responses).

Regarding the markedness senses, the results indicated that the category which received the highest scores of incorrect responses was markedness as complexity (60\% incorrect responses, $40 \%$ correct responses). It was followed by markedness as difficulty (56\% incorrect responses, $44 \%$ correct responses) and markedness as abnormality (50\% incorrect responses, $50 \%$ correct responses).

A preliminary study by author \& author (ibid) had shed light to the importance of markedness, and shown that adult Turkish learners of English are sensitive to lexical items which are marked in terms of 'complexity' and 'difficulty' as opposed to 'abnormality'. This was an unexpected finding considering that the markedness concept is associated with abnormality and infrequent words which are difficult in terms of abnormality should have been a source of difficulty.

The study had further suggestions which enlightened the present study; these are respectively 1) the subjects encountering less difficulty in comprehending infrequent words may not be a reflection of their linguistic competence, but rather a direct effect of the type of determination strategy they used, 2) infrequent words can be interpreted by guessing the meaning from the textual context and through this strategy a learner can overcome a difficult constraint such as frequency or abnormality. It is highly unlikely that the subjects are able to use this same strategy with lexical items which they can recognize, but not fully comprehend, and must therefore use other determination strategies or resort to their linguistic competence. Lexical items which fit the latter condition are most likely to be marked in terms of complexity and difficulty and therefore create difficulty. This finding therefore highlights the need for a closer examination of the subjects' use of determination strategies, since an overreliance on guessing the meaning of a word from its textual context may indeed reflect their lack of other linguistic skills. This we hope to address in research question two.

[Insert Table 2 here]

\subsection{Research Question 2. Which Determination Strategies Do Turkish Adult Learners Use in L2 VL?}

In order to investigate the strategies that the subjects of the present study used most widely the data were analysed using descriptive statistics and SPPS (16.0) program. Cross-tabulation tables were used to display the type of strategies (see Table 3). As depicted inthe table, the subjects' strategy choice is not random and appears to be influenced by the type of markedness constraints in which the target lexical items belongs to (see Table 1 for key). The previous study which investigated the influence of markedness in VL suggested that markedness may determine the strategy choice which the learner resorts to (Yildiz and Ozek, ibid), and this supposition is confirmed by the present study.

The results in Table 3 shows that subjects preferred to use guess from textual context strategy more dominantly with lexical items that are marked in terms of "abnormality". Often guessing from textual context is a strategy which is promoted in reading. In the words of Goodman, reading is a "psycholinguistic guessing game" (Goodman 1967). 
Schmitt (1997) and Zechmeister et.al (1993) found guessing as a useful and most preferred determination strategy in VL. The present study showed that Turkish subjects seemed to overuse this strategy which is not so widely attested (Erten, 1998) and has proven to be the least useful strategy with this sample group. This is an important finding in terms of identifying subjects' motive for each strategy choice.

Previous studies which support or refute (Nassaji, 2003; Bensaussan \& Laufer, 1984) 'guessing from textual context' strategy do not examine the correlation between the strategy usage and the make-up of the lexical items. The relationship between the strategy usage and markedness constraints therefore needs to be examined collectively rather than in isolation.

A further finding has revealed that the subjects are using strategies either simultaneously in strategy clusters or in sequences, in strategy chains. This suggests that Strategy Based Instruction (SBI) should follow the 'interactive approach' (Graham, 1997) in order to promote dual usage of both top-down and bottom-up language processing. Such approach will encourage students to use varying strategies and this in return will enable the learners to interpret the lexical items according to the markedness constraint they belong to. Being able to act accordingly is a useful skill since the findings have supported the correlation between the strategy choice and markedness constraint.

The last and most important finding in terms of identifying the subjects' strategy usage skills is about learners' interpretations without using any strategy- i.e. null-strategy. The results indicate that,students misinterpret the items when they use null-strategy. The frequency analysis revealed that the misinterpretation of the items variesaccording to the markedness constraints, i.e. $19 \%$ of the misinterpreted responses are in relation to the difficulty constraint, $33 \%$ for complexity and 35\% for abnormality. In sum, the majority of the students' usage of null-strategy is driven by the abnormality constraint. This further suggests that there may be a correlation between null-strategy and markedness constraints.

\subsection{Research Question 3. What Type of Input is More Effective in L2 VL?}

The study also investigated the influence of the input type in VL, which is the third variable. The responses that the subjects gave after the input provision was examined by using descriptive analysis (see Table 3). The results of the analysis indicated that the subjects achieved higher correct interpretations for the lexical items when they were given explicit input (the total number of the correct responses after explicit input: 84, and after implicit input: 64). It seems that they find the explicit input more useful in recognising the lexical items or interpreting the meaning of the items. This finding is further confirmed by the fact that the subjects' correct responses for the items did not increase significantly after the researchers provided implicit input (correct responses before input: 57, after input: 64). Whereas their correct responses after explicit input improved significantly (correct responses before input: 53, after input: 84).

\section{[Insert Table 3 here]}

These results may indicate that input type may have an effect on VL skills of the subjects. Not only the type of input but also the application of input may also affect learners' performance. It would also be possible that learners' strategy choice and input type might lead to learners for success in VL. This led the researchers to seek the answer for the next research question.

\subsection{Research Question 4. Is there any Relationship among Markedness Constraints, Strategy Choice and Input Type in $L 2 V L$ ?}

The final research question of the present study was to examine the possible relationship between the markedness constraints, input type and strategy choice in L2 VL. The relationships between the variables are analysed respectively. Firstly, descriptive statistics was used to explore the relationship using SPSS 16.0. Cross-tabulation tables (contingency tables) were used to examine and display the relationship between these categorical variables. A summary of these tables are presented in Table 3. As can be seen in Table 3, the subjects had the highest score for incorrect responses for those lexical items in terms of 'complexity'. The least scores were obtained from the items in the 'abnormality' category. In other words, the subjects had difficulties in recognizing the items in this category. Besides, the subjects attempted to use leastvaried strategies for the lexical items in the 'abnormality' category than those in other categories (abnormality: 7 strategies, complexity: 12 strategies, \& difficulty: 8 different strategies were employed). The results also indicated that,the subjects scored incorrect responses mostly for the lexical items that were marked in terms of 'complexity' when they employed null-strategy.

The analysis reveals an interesting result regarding the relationship between strategy and input; the subjects' responses were less correct when they applied variedstrategiesfor each item than when they did notuse (104 strategy entries leading incorrect responses, 76strategy entries leading correct responses). They used more or less the same number of strategies with the items in the explicit and implicit input categories. However, the null-strategy use 
leaded students to more incorrect identification of the items in the implicit category than the explicit one (22 out of 42 incorrect entries in the explicit category, 23 out of 36 incorrect entries in the implicit category). The results suggest that although the subjects employed different strategies but often unconsciously for the identification of the lexical items, input provision did not improve their success. It can be suggested that, the results could be positively changed if the subjects were given strategy training prior to the input session.

Another striking result was about the relationship between markedness and input. The respondents'correct interpretations showed a significant improvement for the items throughout all markedness constraints after explicit input provision. However, the interpretations did not change much with the items after the implicit input provision, except for the items in the abnormality category. This shows that while no relationship is found between markedness and explicit input,a relationship is detected between markedness and the implicit input, particularly with the abnormality category. Another interesting finding shows that,the effective type of input, in this case explicit input, may lead learners to use a variety of strategies more efficiently and this may in return facilitate learning new vocabulary that are marked differently.

\section{Conclusion}

The aim of this study was to investigate the relationship between markedness, determination strategies and input in VL. The study yielded original findings since it followed an experimental approach which investigated the role of three key variables collectively for the first time- i.e. markedness, strategy and input-and tried to pinpoint the relationship between them in L2 VL. These three variables were tested under the MSI model which was also introduced in the present study. The study made use of a think-aloud method, to diagnose the learners' difficulties in learning the target lexical items and identify their strategy choice related to these difficult lexical items. Following this an input session was provided in order to detect the appropriate remedy for L2 VL learning difficulties.

The analysis of the results provides both empirical and pedagogical implications which are discussed under the MSI-model, in where markedness is considered for diagnosing the source of difficulty that the learner faced with, while strategy identifies the learning process, and input provides the treatment. These variables can be considered a 'chain reaction' thus discussed respectively below:

\section{Markedness}

The present study has shown that adult Turkish learners of English are sensitive to lexical items which are marked in terms of 'complexity' and 'difficulty' as opposed to 'abnormality'. Consequently, their strategy choice seemed to be determined by the markedness constraints. This result is important in two respects:

1) the treatment of markedness enables researchers to pinpoint the source of the students' difficulties in L2 VL.

2) the identification of the source of difficulty in return enables researchers to find out the type of strategy that might help learners to cope with certain markedness constraints.

\section{Strategy}

The study has yielded four significant findings in relation to strategy usage. Firstly, the subjects can employ a wide range of strategies, yet fail to correctly interpret the lexical items. For instance, strategies such as 'analyse affixes of roots', 'guess from textual context' and 'analyse parts of speech' found to be used frequently by the subjects, but did not guide them in correct vocabulary interpretation. Secondly, strategy choice appears to be used selectively rather than randomly and the findings indicate that this may be determined by the type of markedness constraints. For instance, 'abnormality' in the present seems to be highly influential on students strategy choice- i.e. 'guess from textual context'. Thirdly, although the study intends to capture the general picture of strategy choice, and not look at individual performance, the findings indicate strategy clustering within the individual level- i.e. the usage of more than one strategy for each lexical item- and this may also be determined by the markedness constraints. The analysis of case performance for strategy clusters and the possibility of a correlation between strategy cluster and markedness constraints remains a vital area for further research. Last but not least, contrary to strategy clustering, the study also revealed cases of null-strategy usage, which seems to be used most widely with lexical items in the complexity category; this in return leads the learners to incorrect vocabulary interpretation.

\section{Input}

The role of input in L2 VL has been widely investigated in various contexts (Nation, 2001; Hulstijn et al., 1996). The term input in previous studies has been considered as a tool for learning or a way of instruction, and therefore either treated as 'intentional/incidential learning' or 'explicit/implicit instruction'. This refers to the former understanding- i.e. the way of learning and is considered as having two types, namely explicit/implicit learning. In the study, the researchers explained some of the target lexical items implicitly; provided a sample sentence where 
each item is used. On the other hand, other lexical items were introduced with only their Turkish equivalences. Explicit input seemed to have more positive effect in VL. In addition to this the learners' strategy choice and input type might lead the learners to success in VL.

The fact that the students' performance declined following implicit input has indicated the possibility that implicit input could be considered as a strategy rather than an input type, since it requires the students to infer the meaning from the text- i.e. 'guess from textual context'. Strategy training for 'guess from textual context' would therefore enable students to make more use of implicit input since this appears to be their least preferred strategy and often last resort, as is the case with marked lexical items in terms of abnormality. This paper does not refute the effectiveness of implicit input, but rather stresses the need for extra training for strategies such as 'guess from textual context' in SBI.

The wider implications of the above findings and areas for future research are considered below:

1) The present study served to examine the relationship between markedness, strategy choice, and input provision in L2 VL and introduced the MSI-model, which we hope will bridge theory to practice and serve as a tool for linguistic and pedagogical enquiry.

2) While a direct relationship was detected between Markedness and Input and Markedness and Strategy the present study also found a possible indirect relationship between Strategy and Input. We suggest that an experimental study could be conducted,in where strategy identification is made both before and after input protocols, in order to examine the possible direct relationship between Strategy and Input. This in return may confirm the rationale of the MSI-model.

3) During the enquiry a sudden interest arose for the researchers to examine the usefulness of the MSI-model not only in understanding the principles of L2 VL, but also in other language skills such as reading and speaking. This interest will be further pursued by the researchers and should also be considered by other researchers working in other closely related disciplines.

4) The MSI-model can be implemented on a wider population who belongs to different age groups, L1/L2 backgrounds, and proficiency level. The MSI-model could also be used in the enquiry of L1 acquisition.

5) Language teachers and students should receive training in markedness awareness, and this should be incorporated with SBI. The underlying purpose of the SBI should not only aim to teach strategies in isolation, but also and most importantly, teach these strategies according to the make-up of the lexical items. This in return will, we hope, help to eliminate null-strategy. This suggestion in return should promote effective dual usage of top-down and bottom-up teaching methods in VL.

To put in a nut shell, the findings outlined above highlight the importance of the MSI-model in understanding L2 VL, as it has revealed the possible correlation between three key variables considered in the present study.The MSI-model and can also therefore appeal to a wider population- i.e. teachers, educators, curriculum and material designers, and researchers who are seeking to bridge theory to practice. Henceforth, the central fulfillment of the MSI-model, we hope, is that it has given way to refute such comments as below, which discourage interdisciplinary research:

People who are doing applied work- whether they are teachers, doctors or engineers- should pay attention to what's going on in the sciences. But they should also recognise that the sciences aren't going to give them their answers. (Chomsky, 2001: 2)

\section{References}

Abraham, R., \& Vann, R. (1987). Strategies of two language learners: A case study. In Wenden, A. and J. Rubin (Eds.), Learner Strategies: Implications for the Second Language Teacher and Researcher. Englewood Cliffs, NJ: Prentice Hall.

Battistella, E. L. (1990). Markedness: The Evaluative Superstructure of Language. SUNY Series in Linguistics.

Bensoussan, M., \& Laufer, B. (1984). Lexical guessing in context in EFL reading comprehension. Journal of Research in Reading, 7(1), 15-32. http://dx.doi.org/10.1111/j.1467-9817.1984.tb00252.x

Catalan, R. M. J. (2003). Sex differences in L2 vocabulary learning strategies. International Journal of Applied Linguistics, 13(1), 54-77. http://dx.doi.org/10.1111/1473-4192.00037

Chamot, A. U., Barnhardt, S., El-Dinary P. B., \& Robbins, J. (1999). The Learning Strategies Handbook. In Griffiths, C, Lessons From Good Language Learners. Cambridge: CUP.

Chomsky, N. (2001). Chomsky gives advice to teachers on the use of science. In Pacitti, D, EL teaching matters. 
Chomsky, N., \& Halle, M. (1968). The sound pattern of English. New York: Harper \& Row.

Davidson, L. (1997). An Optimality Theoretic Approach to Second Language Acquisition. MA thesis in Linguistics. Brown University.

Ellis, N. C. (1994). Implicit and explicit vocabulary acquisition. In Schmitt, N. \& M, McCarthy (Eds.), Vocabulary: Description, Acquisition and Pedagogy. Cambridge: CUP.

Ellis, N. C. (1995). Consciousness in second language acquisition. In Schmitt, N. \& M. McCarthy (Eds.), Vocabulary: Description, Acquisition and Pedagogy. Cambridge: CUP.

Ellis, R. (1994). The Study of Second Language Acquisition. Oxford: Oxford University Press.

Gass, S., \& Mackey, A. (2006). Input, interaction and output: An overview. AILA Review, 19, 3-17. http://dx.doi.org/10.1075/aila.19.03gas

Ghazal, L. (2007). Learning Vocabulary in EFL Contexts through Vocabulary Learning Strategies. Novitas Royal, $1(2), 84-91$

Gnanadesikan, A. E. (2004). Markedness and faithfulness constraints in child phonology. In Kager, R., Pater, J. and Zonneveld, W. (Eds.), Constraints in Phonological Acquisition. Cambridge: Cambridge University Press. pp. 73-108. [ROA-76]

Goodman, K. S. (1967). Reading: A psycholinguistic guessing game. In Aronoff, M. \& J. Rees-Miller (Eds.), Blackwell Handbook of Linguistics (pp. 664-672). Oxford, England: Blackwell.

Graham, S. (1997). Effective Language Teaching. Clevedon: Multilingual Matters.

$\mathrm{Gu}$, P. Y. (2005). Vocabulary learning strategies in the Chinese EFL context. Singapore: Marshall Cavendish International Private Limited.

Harley, B., \& Hart. D. (2000). Vocabulary learning in the content-oriented second-language classroom: Student perceptions and proficiency. Language Awareness, 9(2), 78-96. http://dx.doi.org/10.1080/09658410008667139

Haspelmath, M. (2006). Against markedness (and what to replace it with). Journal of Linguistics, 42, 25-70

Hulstijn, J. H., Hollander, M., \& Greidanus, T. (1996). Incidental Vocabulary Learning by Advanced Foreign Language Students: the Influence of Marginal Glosses, Dictionary Use, and Reoccurrence of Unknown Words. Modern Language Journal, 80(3), 327-339

Jakobson, R. (1968). Child Language, Aphasia, and Phonological Universals. Tr. A. Keiler. The Hague: Mouton. (The 1941 German text is reprinted in Jakobson 1962)

Kojic-Sabo, I., \& Lightbown. P. M. (1999). Student's approaches to vocabulary learning and their relationship to success.Modern Language Journal, 83(2), 176-92

Krashen, S. (1985). The Input Hypothesis: Issues and Implications. Longman. [Online] Available: http://homepage.ntlworld.com/vivian.c/SLA/Krashen.htm

Krashen, S. (1989). We Acquire Vocabulary and Spelling by Reading: AdditionalEvidenceforthe Input Hypothesis. The Modern LanguageJournal, 73(4), 440-464

Larsen-Freeman, D., \& Long, M. H. (1991). An introduction to second language acquisition research. London.

Leech, G., Rayson, P., \& Wilson, A. (2001). Word frequencies in Written and Spoken English: based on the British National Corpus. Longman.

Leeke, P., \& P. Shaw. (2000). Learners' independent records of vocabulary. System, 28(2), 272-89

Lewis, M. (2000). Introduction. In M. Lewis \& Conzett, J (Eds.), Teaching collocation: further developments in the lexical approach. Hove: Language Teaching Publications. pp. 8-9

McCarthy, J., \& Prince, A. (1994). The emergence of the unmarked: Optimality in prosodic morphology. Proceedings of the North East Linguistics Society, 24, 333-379

Nassaji, H. (2003). L2 vocabulary learning from context: Strategies, knowledge sources, and their relationship with success in L2 lexical inferencing. TESOL Quarterly, 37(4), 645-670. http://dx.doi.org/10.2307/3588216

Nation, I. S. P. (2001). Learning vocabulary in another language. Cambridge University Press. Cambridge, New York.

Nation, I. S. P. (2006). How large a vocabulary is needed for reading and listening? Canadian Modern Language Review, 63, 59-82 
Oxford, R. (1990). Language learning strategies: What every teacher should know. New York: Newbury House.

Oxford, R. (1993). Research on second language learning strategies. In Xuesong (Andy) Gao, Strategic Language Learning: The Roles of Agency and Context. Multilingual Matters.

Parry, K. (1991). Building a vocabulary through academic reading. TESOL Quarterly, 25(4), 629-53

Parry, K. (1993). The social construction of reading strategies: New directions for research. Journal of Research in Reading, 16(2), 148-58

Rice, K. (2003). Featuralmarkedness in phonology: variation. In Cheng, L \& Sysbesma, R (Eds.), The second Glot International state-of-the-article book. Berlin: Mouton de Gruyter. pp. 389- 429

Rubin, J. (1975). What the "Good Language Learner" can teach us? TESOL Quarterly, 9(1)

Rubin, J. (1990). How learner strategies can inform language teaching. In Vee Harris.Adapting Classroom-based Strategy Instruction to a Distance Learning Context. TESL-EJ, 7(2)

Sanaoui, R. (1995). Adult Learner's Approaches to Learning Vocabulary in Second Languages. Modern Language Journal, 79, 15-28

Schmitt, N. (1997). Vocabulary learning strategies. In Schmitt, N. and M. McCarthy (Eds.), Vocabulary: Description, Acquisition, and Pedagogy. Cambridge University Press.

Segler, T. M, Pain, H., \& Sorace A. (2002). Second Language Vocabulary Acquisition and Learning Strategies in ICALL Environments. Computer Assisted Language Learning, 15(4). http://dx.doi.org/10.1076/call.15.4.409.8272

Spolsky, B. (1989). Conditions for Second Language Learning: Introduction to a General Theory. Oxford University Press.

Trimino, A., \& Ferguson, N. (1994). Intensive Input in Language Acquisition. Paper presented at the Annual Central States Conference on the Teaching of Foreign Languages. Kansas, USA.

Trubetzkoy, N. (1939). Grundzüge der Phonologie (Principles of Phonology). Travaux du cerclelinguistique de Prague 7.

VanPatten, B. (1996). Input Processing and Grammar Instruction in Second Language Acquisition. Ablex Publishing Corporation, NJ, USA.

Yildiz \& Ozek. (2009). The Role of Markedness in Vocabulary Learning. In Proceedings of the International Conference of Technology, Education and Development (ICERI 2009). ISBN: 978-84-613-2955-7.

Zechmeister, E. B. D’Anna, C. A., Hall, J. W., Paus, C. H., \& Smith, J. A. (1993). Metacognitive and other knowledge about the mental lexicon: Do we know how many words we know? Applied Linguistics, 14(2), 188-206. http://dx.doi.org/10.1093/applin/14.2.188

Table 1. Determination strategies (Schmitt, 1997)

\begin{tabular}{|l|}
\hline \multicolumn{1}{|c|}{ Determination Strategies } \\
\hline 1) Analyse parts of speech \\
\hline 2) Analyse affixes of roots \\
\hline 3) Check for L1 cognates \\
\hline 4) Guess from textual context \\
\hline 5) Sound association \\
\hline 6) Mental picture \\
\hline 7) Use in sentence \\
\hline 8) Synonym/ antonym \\
\hline 9) Keyword \\
\hline 10) Learning situation \\
\hline 11) preceding location \\
\hline 12) proceeding location \\
\hline 13) L2 cognate \\
\hline
\end{tabular}


Table 2. Frequency analysis of the subjects' comprehension of the target lexical items according to the markedness constraints

\begin{tabular}{|c|c|c|c|c|}
\hline \multirow{2}{*}{\multicolumn{2}{|c|}{$\begin{array}{l}\text { Type of } \\
\text { markedness }\end{array}$}} & \multirow{3}{*}{$\begin{array}{l}\text { Lexical Items } \\
\text { Lasting (ex) }\end{array}$} & \multicolumn{2}{|l|}{ Think-Aloud Procedure } \\
\hline & & & \multirow{2}{*}{$\begin{array}{l}\text { Correct interpretation } \\
5 \\
\end{array}$} & \multirow{2}{*}{$\begin{array}{l}\text { Incorrect interpretation } \\
5\end{array}$} \\
\hline \multirow{9}{*}{ 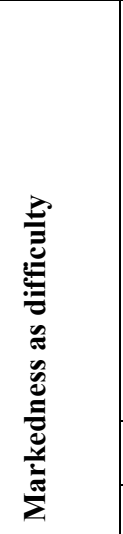 } & \multirow[t]{7}{*}{ Morphology } & & & \\
\hline & & Remote (ex) & 5 & 5 \\
\hline & & Durable (ex) & 6 & 4 \\
\hline & & Defunct (im) & 5 & 5 \\
\hline & & Weaponry (im) & 4 & 6 \\
\hline & & Henceforth (ex) & 6 & 4 \\
\hline & & Hereby (im) & 1 & 9 \\
\hline & \multicolumn{2}{|c|}{ Total for morphology } & $32=45 \%$ & $38=55 \%$ \\
\hline & \multirow{3}{*}{ Syllable count } & Encapsulated (ex) & - & 10 \\
\hline & & $\begin{array}{l}\text { Manufactured } \\
\text { (im) }\end{array}$ & 6 & 4 \\
\hline & & Picturesque (ex) & 6 & 4 \\
\hline & \multicolumn{2}{|c|}{ Total for syllable account } & $12=40 \%$ & $18=60 \%$ \\
\hline \multicolumn{3}{|c|}{ Total for difficulty } & $44=44 \%$ & $56=56 \%$ \\
\hline \multirow{11}{*}{ 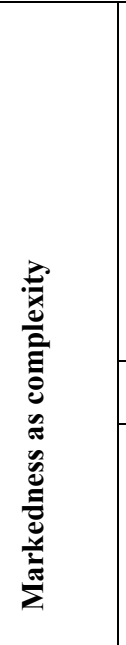 } & \multirow[t]{6}{*}{ Semantics } & Funeral (ex) & 6 & 4 \\
\hline & & Exchange (im) & 10 & - \\
\hline & & Season (ex) & - & 10 \\
\hline & & Vessels (ex) & 2 & 8 \\
\hline & & Mobile (im) & 4 & 6 \\
\hline & & Notable (im) & 5 & 5 \\
\hline & \multicolumn{2}{|c|}{ Total for semantics } & $27=45 \%$ & $33=55 \%$ \\
\hline & \multirow[t]{4}{*}{ Margin length } & Swap (im) & 1 & 9 \\
\hline & & Substance (ex) & 7 & 3 \\
\hline & & Ornaments (ex) & 5 & 5 \\
\hline & & Straw (im) & - & 10 \\
\hline & \multicolumn{2}{|c|}{ Total for margin length } & $13=33 \%$ & $27=67 \%$ \\
\hline \multicolumn{3}{|c|}{ Total for complexity } & $40=40 \%$ & $60=60 \%$ \\
\hline \multirow[t]{3}{*}{$\approx$} & \multirow[t]{6}{*}{ Frequency } & Barter (im) & 6 & 4 \\
\hline & & Hoard (im) & 3 & 7 \\
\hline & & Supplanted (ex) & - & 10 \\
\hline \multirow{3}{*}{ 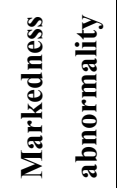 } & & Secluded (ex) & 3 & 7 \\
\hline & & Primitive (ex) & 8 & 2 \\
\hline & & Must (im) & 10 & - \\
\hline \multicolumn{3}{|c|}{ Total for abnormality } & $30=50 \%$ & $30=50 \%$ \\
\hline
\end{tabular}


Table 3. Subjects' strategy choices according to markedness constraints, their performance before and after the input provision.

\begin{tabular}{|c|c|c|c|c|c|c|c|}
\hline \multirow{3}{*}{$\begin{array}{l}1 \\
1\end{array}$} & \multirow{3}{*}{$\begin{array}{c}\begin{array}{c}\text { Lexical } \\
\text { Items }\end{array} \\
\text { Encapsulated }\end{array}$} & \multirow{3}{*}{$\begin{array}{c}\text { Type of } \\
\text { markedness } \\
\text { Difficulty }\end{array}$} & \multicolumn{2}{|c|}{$\begin{array}{l}\text { Responses before input \& strategy choices used in think aloud } \\
\text { sessions * }\end{array}$} & \multirow{3}{*}{$\begin{array}{c}\begin{array}{c}\text { Input } \\
\text { type }\end{array} \\
\text { Explicit }\end{array}$} & \multirow{2}{*}{\multicolumn{2}{|c|}{$\begin{array}{c}\text { Responses } \\
\text { after input } \\
\text { correct incorrect }\end{array}$}} \\
\hline & & & \multicolumn{2}{|l|}{1 (correct) } & & & \\
\hline & & & $0=$ & $\begin{array}{l}10=6 \text { strategy } 1,1 \text { strategy } 2,1 \\
\text { strategy } 3,2 \text { strategy } 0\end{array}$ & & 4 & 6 \\
\hline 2 & Picturesque & Difficulty & $\begin{array}{l}6=2 \text { strategy } 4,2 \text { strategy, } \\
(8), 1 \text { strategy } 2,1 \text { strategy } 0\end{array}$ & $\begin{array}{l}4=2 \text { Strategy } 8,1 \text { strategy } 4,1 \\
\text { strategy } 2,0 \text { strategy } 0\end{array}$ & Explicit & 9 & 1 \\
\hline 3 & Henceforth & Difficulty & $\begin{array}{l}6=3 \text { strategy }(1), 2 \\
\text { strategy } 6,1 \text { strategy } 0\end{array}$ & $\begin{array}{l}4=1 \text { strategy }(6), 1 \text { strategy } 3,2 \\
\text { strategy } 0\end{array}$ & Explicit & 4 & 6 \\
\hline 4 & Lasting & Difficulty & $\begin{array}{l}5=2 \text { strategy }(8), 1 \\
\text { strategy } 4,2 \text { strategy } 0\end{array}$ & $\begin{array}{l}5=2 \text { strategy (4), } 1 \text { strategy } 8, \\
1 \text { strategy } 2,1 \text { strategy } 0\end{array}$ & Explicit & 8 & 2 \\
\hline 5 & Durable & Difficulty & $\begin{array}{l}6=2 \text { strategy }(1), 1 \\
\text { strategy } 3,1 \text { strategy } 2,1 \\
\text { strategy } 0\end{array}$ & $\begin{array}{l}4=2 \text { strategy }(3), 1 \text { strategy } 2,1 \\
\text { strategy } 1,1 \text { strategy } 0\end{array}$ & Explicit & 7 & 3 \\
\hline 6 & Weaponry & Difficulty & $\begin{array}{l}4=1 \text { strategy }(2), 3 \\
\text { strategy } 0\end{array}$ & $\begin{array}{l}6=4 \text { strategy } 2,1 \text { strategy } 4,1 \\
\text { strategy } 9,0 \text { strategy } 0\end{array}$ & Explicit & 10 & - \\
\hline \multicolumn{2}{|c|}{ Total } & \multicolumn{2}{|c|}{$\begin{array}{l}27=45 \% \text { correct responses } \\
1,4 \text { st } 8,3 \text { st } 2,3 \text { st } 4, \underline{8 \text { st } 0}\end{array}$} & $\begin{array}{l}33=\% 55 \text { incorrect responses } \\
7 \text { times st } 1,8 \text { times st } 2,4 \text { st } 4,4 \text { st } 3 \text {, a }\end{array}$ & \multicolumn{3}{|c|}{$\begin{array}{l}42=70 \% 18=30 \% \\
6 \text { st } 0\end{array}$} \\
\hline 7 & Season & Complexity & $0=$ & $\begin{array}{l}10=3 \text { Strategies } 4 \& 6,2 \\
\text { strategy } 2,2 \text { strategy } 0\end{array}$ & Explicit & 5 & 5 \\
\hline 8 & Funeral & Complexity & $\begin{array}{l}4=2 \text { strategy } 2,1 \text { strategy } \\
10,1 \text { strategy } 11,3 \text { strategy } \\
0\end{array}$ & $6=1$ strategy 1,2 strategy 0 & Explicit & 8 & 2 \\
\hline 9 & Ornaments & Complexity & $\begin{array}{l}5=1 \text { strategy } 4,4 \\
\text { strategy } 0\end{array}$ & $\begin{array}{l}5=2 \text { strategy } 4,1 \text { strategy } 1,2 \\
\text { strategy } 0\end{array}$ & Explicit & 7 & 3 \\
\hline 10 & Vessels & Complexity & $\begin{array}{l}2=1 \text { strategy } 11,1 \\
\text { strategy } 0\end{array}$ & $\begin{array}{l}8=3 \text { strategy } 4,1 \text { strategy } 7,1 \\
\text { strategy } 11,1 \text { strategy } 1,2 \text { strategy } 0\end{array}$ & Explicit & 5 & 5 \\
\hline 11 & Substance & Complexity & $\begin{array}{l}7=4 \text { strategy } 2,1 \text { strategy } \\
3,2 \text { strategy } 0\end{array}$ & $\begin{array}{c}3=1 \quad \text { strategy } 7,1 \text { strategy } 2,1 \\
\text { strategy } 0\end{array}$ & Explicit & 7 & 3 \\
\hline \multicolumn{2}{|c|}{ Total } & \multicolumn{2}{|c|}{$\begin{array}{l}18=33 \% \text { correct responses } \\
6 \text { times st } 2,2 \text { st } 11 \& 9 \text { st } 0\end{array}$} & $\begin{array}{l}32=67 \% \text { incorrect responses } \\
\quad 8 \text { times st } 4,3 \text { st } 2,3 \text { st } 1,8 \text { st } 0\end{array}$ & \multicolumn{3}{|c|}{$32=67 \% \quad 18=33 \%$} \\
\hline 12 & Supplanted & Abnormality & $0=$ & $\begin{array}{l}10=2 \text { strategy } 2,2 \text { strategy } 1,1 \\
\text { strategy } 4,1 \text { strategy } 5,4 \text { strategy } 0\end{array}$ & Explicit & 1 & 9 \\
\hline 13 & Primitive & Abnormality & $\begin{array}{l}8=2 \text { strategy } 2,1 \text { strategy } \\
6,5 \text { strategy } 0\end{array}$ & $2=2$ strategy 0 & Explicit & 9 & 1 \\
\hline \multicolumn{2}{|l|}{ Total } & \multicolumn{6}{|c|}{$\begin{array}{lc}8=40 \% \text { correct reponses } & 12=60 \% \text { incorrect reponses } \quad 10=50 \% \quad 10=50 \% \\
2 \text { times st } 2,1 \text { st } 6,5 \text { st } 0 & 2 \text { times st } 2,2 \text { st } 1,1 \text { st } 4,6 \text { st } 0\end{array}$} \\
\hline 1 & Hereby & Difficulty & $\begin{array}{l}1=1 \text { strategy }(3), 0 \\
\text { strategy } 0\end{array}$ & $\begin{array}{l}9=3 \text { strategy }(6) \& 2 \text { strategy }(1), 1 \\
\text { strategy } 3,1 \text { strategy } 2,2 \text { strategy } 0\end{array}$ & Implicit & 3 & 7 \\
\hline 2 & Remote & Difficulty & $\begin{array}{l}5=4 \text { strategy }(2), 1 \\
\text { strategy } 8,0 \text { strategy } 0\end{array}$ & $\begin{array}{l}5=2 \text { strategy }(3), 1 \text { strategy } 2,2 \\
\text { strategy } 0\end{array}$ & Implicit & 7 & 3 \\
\hline 3 & Defunct & Difficulty & $\begin{array}{l}4=4 \text { strategy }(2), 0 \\
\text { strategy } 0\end{array}$ & $\begin{array}{l}6=2 \text { strategy (1) \& } 2 \text { strategy }(2), 1 \\
\text { strategy } 3,1 \text { strategy } 0\end{array}$ & Implicit & 3 & 7 \\
\hline 4 & Manufactured & Difficulty & $\begin{array}{l}6=2 \text { Strategy }(3), 1 \text { strategy } \\
2,1 \text { strategy } 1,2 \text { strategy } 0\end{array}$ & $\begin{array}{l}4=1 \text { strategy } 5,1 \text { strategy } 2,2 \\
\text { strategy } 0\end{array}$ & Implicit & 7 & 3 \\
\hline \multicolumn{2}{|c|}{ Total } & \multicolumn{2}{|c|}{$\begin{array}{c}16=40 \% \text { correct responses } \\
9 \text { times st } 2,3 \text { st } 3,2 \text { st } 0\end{array}$} & $\begin{array}{l}24=60 \% \text { incorrect responses } \\
4 \text { times st } 1,4 \text { st } 2,4 \text { st } 3,7 \text { st } 0\end{array}$ & \multicolumn{3}{|c|}{$20=50 \% \quad 20=50 \%$} \\
\hline 5 & Exchange & Complexity & $\begin{array}{l}10=4 \text { strategy } 8,1 \text { strategy } \\
1,5 \text { strategy } 0\end{array}$ & $0=$ & Implicit & 9 & 1 \\
\hline 6 & Notable & Complexity & $\begin{array}{l}5=2 \text { strategy } 1,2 \text { strategy } \\
2,1 \text { strategy } 5,0 \text { strategy } \\
0\end{array}$ & $\begin{array}{l}5=2 \text { strategy } 2,1 \text { strategy } 6,1 \\
\text { strategy } 0\end{array}$ & Implicit & 7 & 3 \\
\hline 7 & Swap & Complexity & $\begin{array}{l}1=1 \text { strategy } 3,0 \text { strategy } \\
0\end{array}$ & $\begin{array}{l}9=4 \text { strategy } 2,2 \text { strategy } 3,3 \\
\text { strategy } 0\end{array}$ & Implicit & 2 & 8 \\
\hline 8 & Straw & Complexity & $0=$ & $\begin{array}{l}10=3 \text { strategy } 4,1 \text { strategy } 8,6 \\
\text { strategy } 0\end{array}$ & Implicit & 1 & 9 \\
\hline 9 & Mobile & Complexity & $\begin{array}{l}4=2 \text { strategy } 12,2 \\
\text { strategy } 6,0 \text { strategy } 0\end{array}$ & $\begin{array}{l}6=3 \text { strategy } 12,2 \text { strategy } 6,1 \\
\text { strategy } 0\end{array}$ & Implicit & 9 & 1 \\
\hline \multicolumn{2}{|c|}{ Total } & \multicolumn{2}{|c|}{$\begin{array}{c}20=40 \% \text { correct responses } \\
4 \text { times st } 8,3 \text { st } 1,2 \text { st } 2,5 \text { st } 0 \\
\end{array}$} & $\begin{array}{l}30=60 \% \text { incorrect responses } \\
6 \text { st } 2,3 \text { st } 6,3 \text { st } 4,2 \text { st } 3, \& 11 \text { st } 0\end{array}$ & \multicolumn{3}{|c|}{$28=56 \% \quad 22=44 \%$} \\
\hline 10 & Barter & Abnormality & $\begin{array}{l}6=3 \text { strategy } 2,1 \text { strategy } \\
1,1 \text { strategy } 6,1 \text { strategy } 0\end{array}$ & $\begin{array}{l}4=2 \text { strategy } 2,1 \text { strategy } 4,1 \\
\text { strategy } 0\end{array}$ & Implicit & 5 & 5 \\
\hline 11 & Secluded & Abnormality & $\begin{array}{l}2=1 \text { strategy } 2,1 \\
\text { strategy } 3,0 \text { strategy } 0\end{array}$ & $\begin{array}{l}8=5 \text { strategy } 2,1 \text { strategy } 3,1 \\
\text { strategy } 1,1 \text { strategy } 0\end{array}$ & Implicit & 1 & 9 \\
\hline 12 & Must & Abnormality & $\begin{array}{c}10=3 \text { strategy } 1,1 \text { strategy } \\
2,1 \text { strategy } 5,5 \text { strategy } 0\end{array}$ & $0=$ & Implicit & 10 & - \\
\hline 13 & Hoard & Abnormality & $\begin{array}{l}3=3 \text { strategy } 4,0 \text { strategy } \\
0\end{array}$ & $7=4$ strategy 4,3 strategy 0 & Implicit & - & 10 \\
\hline \multicolumn{2}{|l|}{ Total } & & $\begin{array}{l}1=52 \% \text { correct responses } \\
\text { nes } 2,4 \text { st } 1,3 \text { st } 4,6 \text { st } 0\end{array}$ & $\begin{array}{l}19=48 \% \text { incorrect responses } \\
7 \text { times st } 2,5 \text { st } 4,5 \text { st } 0\end{array}$ & \multicolumn{3}{|c|}{$16=40 \% \quad 24=60 \%$} \\
\hline
\end{tabular}

*See Table 1 for the codes of strategies 


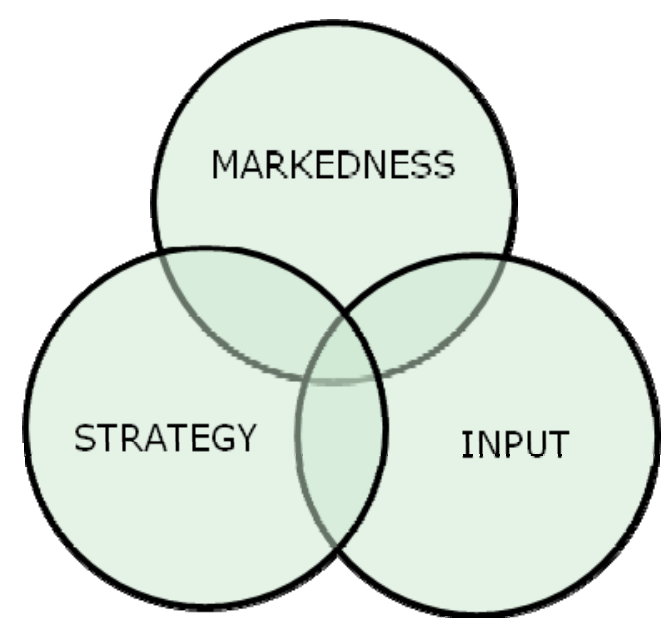

Figure 1. The MSI -Model in L2 VL

\section{Appendix}

\section{Reading Text}

\section{Money}

Aristotle, the Greek philosopher, encapsulated the four chief qualities of money some 2,000 years ago. It must be lasting and easy to recognize, to divide, and to carry about. In other words it must be, 'durable and mobile'. When we think of money today, we picture it either as round, flat pieces of metal which we call coins, or as printed paper notes. But there are still parts of the world today where coins and notes are defunct. They will buy nothing, and a traveler might starve if he had none of the notable local 'money' to swap for food.

Among secluded peoples, who are not often reached by traders from outside, commerce usually means barter. There is a directexchange of goods. Hereby it is fish for vegetables, straw for grain, or various kinds of food in exchange for pots, weaponry, or other manufactured goods. For this kind of simple trading, money is not needed, but there is often something that everyone wants and everybody can use, such as salt to season food, shells for ornaments, or iron and copper to make into tools and vessels. These things-salt, shells or metals-are still used as money in some parts of the world today. Salt may seem rather a strange substanceto use as money, but in countries where the food of the people is mainly vegetable, it is often a must.

Henceforth, coins and notes have supplanted nearly all the more picturesque forms of money. In one or two of the more remote countries people still hoardit for future use on ceremonial occasions such as weddings and funerals. Nevertheless, examples of primitive money will soon be found only in museums. 